\title{
A macrolide-lincosamide-streptogramin B resistance determinant from Bacillus anthracis 590: cloning and expression of ermJ
}

\author{
HeE-Sun Kim, Eung-Chil Chol* and Byong-KaK Kim \\ College of Pharmacy, Seoul National University, San 56-1, Shinlim-Dong, Kwanack-Gu, Seoul 151-742, Korea
}

(Received 13 July 1992; revised 23 October 1992; accepted 10 November 1992)

\begin{abstract}
The inducible macrolide-lincosamide-streptogramin B resistance determinant, ermJ, from Bacillus anthracis 590 was cloned in Escherichia coli CSH26. The DNA sequence of ermJ was similar to that of ermK or ermD from $B$. licheniformis, suggesting that ermK-like genes have been distributed in Bacillus strains by transposition. Expression of ermJ was achieved in a $B$. subtilis minicell system, and the rRNA methyltransferase product of erm $J$ was purified. The molecular mass of the enzyme was $58 \mathrm{kDa}$, and it was concluded to be a homodimer. Its biochemical characteristics were different from those of ermC methyltransferase.
\end{abstract}

\section{Introduction}

MLS antibiotics (macrolides, lincosamides and substances related to streptogramin B) inhibit protein biosynthesis, their site of action being the 50S ribosomal subunit. Resistance to MLS antibiotics can be brought about by two mechanisms (reviewed by Dubnau 1984): one is through modification of ribosomal proteins L4 or L22 in Escherichia coli or L17 in B. subtilis; the other is through alteration of the secondary structure of $23 \mathrm{~S}$ rRNA causing a loss of affinity for MLS antibiotics. The latter involves base substitution by mutation, and results in $N^{6}$-mono- or $N^{6}, N^{6}$-dimethylation at a specific adenine residue. If the resistance is caused by alteration of the target site of erythromycin (Em) on 23S rRNA, crossresistance to MLS antibiotics should be obtained. Resistance through inactivating MLS antibiotics or impermeability to cell membranes has been shown to occur in E. coli, Staphylococcus aureus, Staph. epidermidis and Streptomyces spp.; here resistance was limited to structurally related antibiotics (reviewed by Leclercq \& Courvalin, 1991).

Mechanisms for regulating expression of MLS resistance genes are classified as translational attenuation

${ }^{*}$ Author for correspondence. Tel. 28807874 ; fax 28865802 .

Abbreviations: Em, erythromycin; MLS, macrolide-lincosamidestreptogramin B; SAM, S-adenosylmethionine.

The nucleotide sequence data reported in this paper have been submitted to GenBank and have been assigned the accession number L08389.
(Weisblum, 1985), translational feedback inhibition (Shivakumar et al., 1980) or autoregulation (Breidt \& Dubnau, 1990). Translational attenuation is the most important mechanism and has been studied intensively. In the case of ermC (Weisblum, 1985) induction occurs, and the process entails activating mRNA encoding a 23S rRNA methyltransferase. Activation involves altering the secondary structure of mRNA, and is brought about by stalling an Em-ribosome complex on a leader region encoding a short polypeptide. The existence of translational attenuation has also been suggested in ermA (Murphy, 1985), ermD (Gryczan et al., 1984), ermG (Monod et al., 1987), ermSF (Kamimiya \& Weisblum, 1988) and ermAM (Horinouchi et al., 1983). In contrast to the translational attenuation associated with most MLS resistance genes, transcriptional regulation has been found in ermK, the MLS-resistant element isolated from B. licheniformis. Kwak et al. (1991) suggested that synthesis of the ermK message is initiated constitutively upstream of the proposed $\rho$ factorindependent terminator, but is completed inducibly downstream of this site.

We have isolated an MLS-resistant strain identified as B. anthracis from a soil sample in Korea (Choi et al., 1989). By colony hybridization, the MLS-resistant element, designated ermJ, has now been cloned from the chromosomal DNA of this strain, and its nucleotide sequence determined. Its leader sequence is compared with those of other erm genes and a possible control mechanism for ermJ expression is proposed. Expression of ermJ was obtained in a $B$. subtilis minicell system. The ermJ gene product (rRNA methyltransferase) was 
isolated, and its molecular mass and biochemical characteristics were determined.

\section{Methods}

Bacterial strains and plasmids. The strains and plasmids used in this study are listed in Table 1.

Cloning of ermJ. Total chromosomal DNA isolated from B. anthracis 590 was digested with various restriction enzymes and hybridized with a $M s p$ I-MspI fragment ( $660 \mathrm{bp}$ ) of ermK containing the upstream region of the structural genes (Southern, 1975; Kwak et al., 1991). In a $B c I$ digest, fragments about $3.0 \mathrm{~kb}$ long hybridized with the probe. These fragments were electroeluted and ligated with pBS42 linearized with BamHI. E. coli CSH26 was transformed with the recombinant plasmids and the transformants were screened by colony hybridization (Davis et al., 1986) with the same probe used in the Southern procedure. Plasmid DNA isolated from four colonies showing positive signals was used to transform $B$. subtilis UOTO277, and the resulting inducible resistance patterns were compared with those of the original B. anthracis 590. The cloned plasmid was named pBA423. For subcloning, HincII-HincII $(1.4 \mathrm{~kb}), \quad$ TaqI-TaqI $(2.0 \mathrm{~kb})$ and BamHI-EcoRV $(1.8 \mathrm{~kb})$ fragments were isolated by electroelution, ligated with appropriately digested pBS42, and used to transform $B$. subtilis UOTO277 (Gryczan et al., 1978). Transformant colonies were selected after 2 days incubation on LB agar containing $\operatorname{Em}\left(10 \mu \mathrm{g} \mathrm{ml}^{-1}\right)$ and chloramphenicol $\left(10 \mu \mathrm{g} \mathrm{ml}^{-1}\right)$.

DNA sequencing of ermJ. The nucleotide sequence of the $1.4 \mathrm{~kb}$ HincII-HincII fragment containing ermJ was determined by the dideoxynucleotide chain termination method (Sanger et al., 1977). A sequencing system with the pGEM-3Zf phagemid vector (Mead \& Kemper, 1988) and the Klenow fragment was used.

Minicell purification. Minicells were purified by the method of Shivakumar et al. (1979). B. subtilis CU403 transformed with pBA423 was grown at $37^{\circ} \mathrm{C}$ in medium GM-1 (Shivakumar et al., 1979) to late exponential phase; then penicillin $\mathrm{G}\left(25 \mathrm{U} \mathrm{ml}^{-1}\right)$ was added and incubation continued for $1 \mathrm{~h}$ more. The cultures were quickly chilled and subsequent steps were performed at $0^{\circ} \mathrm{C}$. The cells were harvested by centrifugation at $12000 \mathrm{~g}$ and resuspended with a few $\mathrm{ml}$ of GM-1 medium lacking methionine and glucose (wash medium); the resulting suspension was layered on a 5-30\% sucrose gradient and centrifuged (Beckman SW28 rotor at $3500 \mathrm{~g}$ ) for $20 \mathrm{~min}$. The cloudy minicell layer was removed with a serum separator and centrifuged for $10 \mathrm{~min}$ at
$20000 \mathrm{~g}$. The pellet was resuspended in 1-2 $\mathrm{ml}$ wash medium, layered on another $5-30 \%(\mathrm{w} / \mathrm{v})$ sucrose gradient and centrifuged as before. The sharper minicell layer was removed, pelleted and resuspended in $2 \mathrm{ml}$ of wash medium; its absorbance at $660 \mathrm{~nm}$ was measured. The minicells were repelleted and resuspended in preservation medium (GM-1 containing $10 \%, \mathrm{v} / \mathrm{v}$, glycerol) at an $A_{660}$ of $2 \cdot 0$. These stock suspensions were quick-frozen and stored at $-70^{\circ} \mathrm{C}$.

Incorporation of $\left[{ }^{35} S\right]$ methionine into B. subtilis minicells. The frozen minicells $(100 \mu \mathrm{l})$ were thawed, resuspended in $1 \mathrm{ml} \mathrm{GM}-1$ medium lacking methionine ( $-\mathrm{Met}$ ), and centrifuged at $10000 \mathrm{~g}$ for $5 \mathrm{~min}$. The minicell pellets were resuspended in $100 \mu \mathrm{l} \mathrm{GM}-1$ ( - Met) medium to which the inducer, $\mathrm{Em}\left(0 \cdot 1 \mu \mathrm{g} \mathrm{ml}^{-1}\right)$, was added and were incubated at $37^{\circ} \mathrm{C}$ for $15 \mathrm{~min}$. Next, $1 \mu 1\left[^{35} \mathrm{~S}\right]$ methionine $\left[1150 \mu \mathrm{Ci} \mathrm{mmol}^{-1}(1 \mathrm{Ci}=\right.$ $37 \mathrm{GBq}$ )] was added, and the mixture was incubated for a further $30 \mathrm{~min}$. The reaction was stopped by adding trichloroacetic acid (final concentration $10 \%, \mathrm{w} / \mathrm{v})$, then $20-30 \mu \mathrm{l}$ sample buffer $(20 \mathrm{~mm}-$

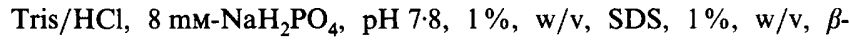
mercaptoethanol) was added to the reaction mixture. The sample was electrophoresed in a $12 \%(\mathrm{w} / \mathrm{v})$ SDS-polyacrylamide gel and the dried gel was exposed to X-ray film.

Isolation of $50 S$ ribosomal subunits from B. subtilis. $50 \mathrm{~S}$ ribosomal subunits were prepared from $B$. subtilis UOTO277 by modifying the methods of Fahnestock et al. (1974). 50S and 30S ribosomal subunits were separated from salt-washed $70 \mathrm{~S}$ ribosomes in $10-30 \%$ sucrose gradients prepared in a buffer containing $10 \mathrm{~mm}-\mathrm{Tris} / \mathrm{HCl}(\mathrm{pH} \mathrm{7.4})$, $30 \mathrm{~mm}-\mathrm{NH}_{4} \mathrm{Cl}, 0.3 \mathrm{~mm}-\mathrm{MgCl}_{2}$ and $6 \mathrm{~mm}-\beta$-mercaptoethanol. Centrifugation was carried out at $50000 \mathrm{~g}$ for $15 \mathrm{~h}$.

Purification of $r R N A$ methyltransferase from $B$. subtilis transformed with $p B A 423$. The enzyme was purified by the method of Shivakumar \& Dubnau (1981). B. subtilis UOTO277 transformed with pBA423 was grown in $101 \mathrm{LB}$ broth to mid-exponential phase and then Em $\left(0.1 \mu \mathrm{g} \mathrm{ml}^{-1}\right)$ was added. After a further $3 \mathrm{~h}$ incubation, cells were

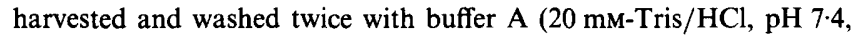
1 mM-EDTA, 60 mM- $\mathrm{NH}_{4} \mathrm{Cl}, 6 \mathrm{mM}-\beta$-mercaptoethanol, $10 \%$ glycerol, $2 \mathrm{mM}-\mathrm{PMSF}$ ) containing $1 \mathrm{M}-\mathrm{KCl}$, then once with buffer A containing $0.05 \mathrm{M}-\mathrm{KCl}$. The cells $(20-30 \mathrm{~g})$ were ground in a mortar with twice their weight of sea sand and resuspended in $80 \mathrm{ml}$ buffer $B$ $(20 \mathrm{~mm}$-Tris/HCl, $\mathrm{pH} 7.4,10 \mathrm{~mm}$-magnesium acetate, $6 \mathrm{~mm}-\beta$ mercaptoethanol, $10 \%$ glycerol, $2 \mathrm{~mm}-\mathrm{PMSF}$ ) containing $60 \mathrm{~mm}-$ $\mathrm{NH}_{4} \mathrm{Cl}$. DNAase $\left(2 \mu \mathrm{g} \mathrm{ml}^{-1}\right)$ was added to the suspension and the mixture was left on ice for $30 \mathrm{~min}$. It was then centrifuged at $30000 \mathrm{~g}$ for $30 \mathrm{~min}$. The resulting supernatant (S30 crude extract) was centrifuged for $4 \mathrm{~h}$ at $105000 \mathrm{~g}$. The ribosomal pellet was resuspended in $50 \mathrm{ml}$ buffer $\mathrm{B}$ containing $1 \mathrm{M}-\mathrm{NH}_{4} \mathrm{Cl}$ and kept on ice overnight. It

Table 1. Bacterial strains and plasmids

\begin{tabular}{|c|c|}
\hline $\begin{array}{l}\text { Strain or } \\
\text { plasmid }\end{array}$ & Description \\
\hline \multicolumn{2}{|l|}{ Bacterial strains } \\
\hline B. anthracis 590 & Source of ermJ (this study) \\
\hline B. subtilis UOTO 277 & $\begin{array}{l}\text { Transformable host for studying expression of plasmid } \\
\text { constructs (Band \& Henner, 1984) }\end{array}$ \\
\hline B. subtilis CU403 & Transformable host for minicell study (Reeve et al., 1973) \\
\hline E. coli $\mathrm{CSH} 26$ & $\begin{array}{l}\text { Transformable host for preparation of } B \text {. anthracis DNA library } \\
\text { for colony hybridization (Miller, 1972) }\end{array}$ \\
\hline \multicolumn{2}{|l|}{ Plasmids } \\
\hline pBS42 & $\begin{array}{l}\text { Plasmid vector for cloning ermJ from B. anthracis DNA (Band } \\
\text { \& Henner, 1984) }\end{array}$ \\
\hline pBA423 & $\begin{array}{l}\text { Derived from pBS42: contains } 2.9 \mathrm{~kb} \mathrm{BclI} \text { fragment of } \\
\text { B. anthracis DNA with ermJ insert (this study) }\end{array}$ \\
\hline
\end{tabular}


was centrifuged again ( $105000 \mathrm{~g}$ for $4 \mathrm{~h}$ ) and the supernatant (high-salt ribosomal wash) was brought to $40 \%$ saturation with $\left(\mathrm{NH}_{4}\right)_{2} \mathrm{SO}_{4}$. After $2 \mathrm{~h}$ at $0{ }^{\circ} \mathrm{C}$, it was centrifuged for $20 \mathrm{~min}$ at $12000 \mathrm{~g}$. The supernatant from this step was brought to $80 \%$ saturation with $\left(\mathrm{NH}_{4}\right)_{2} \mathrm{SO}_{4}$, kept on ice overnight, and centrifuged. The pellet obtained was dissolved in buffer B containing $100 \mathrm{mM}-\mathrm{NH}_{4} \mathrm{Cl}$. The solution was dialysed against buffer $\mathrm{B}$ containing $100 \mathrm{mM}-\mathrm{NH}_{4} \mathrm{Cl}$ for $48 \mathrm{~h}$ at $4{ }^{\circ} \mathrm{C}$. The dialysate was loaded on a phosphocellulose column $(1.5 \times 24 \mathrm{~cm})$

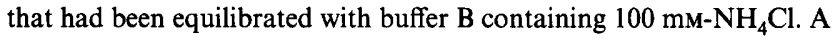
linear gradient of $200 \mathrm{ml} \mathrm{NH}_{4} \mathrm{Cl}(0 \cdot 1-1 \cdot 0 \mathrm{M})$ in buffer $\mathrm{B}$ was applied to elute the enzyme. Fractions $(2 \mathrm{ml})$ were collected, and $10 \mu \mathrm{l}$ samples from each were assayed for methyltransferase activity. The active fractions were pooled, concentrated in an Amicon ultra-filtration cell and stored at $-70^{\circ} \mathrm{C}$.

Assay for $r$ RNA methyltransferase activity. Enzyme activity was assayed by the method of Shivakumar \& Dubnau (1981). The final reaction mixture, containing $40 \mathrm{~mm}-\mathrm{Tris} / \mathrm{HCl}(\mathrm{pH} 7.5), 4 \mathrm{mM}-\mathrm{mag}$ nesium acetate, $60 \mathrm{~mm}-\mathrm{NH}_{4} \mathrm{Cl}, 6 \mathrm{mM}-\beta$-mercaptoethanol, $0.02 \mathrm{~mm}-S$ adenosyl[methyl- $\left.{ }^{3} \mathrm{H}\right]$ methionine (SAM) $\left(10 \mathrm{Ci} \mathrm{mmol}^{-1}\right), 15 \mathrm{pmol}$ of $50 \mathrm{~S}$ ribosomes, and enzyme solution to give a total volume of $50 \mu \mathrm{l}$, was incubated at $37^{\circ} \mathrm{C}$ for $20 \mathrm{~min}$. One unit of enzyme activity was defined as the amount of enzyme required to introduce $1 \mathrm{pmol}$ of methyl groups per $20 \mathrm{~min}$ to $15 \mathrm{pmol}$ of $50 \mathrm{~S}$ ribosomes under the assay conditions described.

\section{Results and Discussion}

\section{Cloning and DNA sequencing of ermJ}

Competent cells of $E$. coli were transformed with a ligated mixture of linearized pBS42 plasmids and sized $B c l$ I-digested $B$. anthracis DNA containing a fragment of approximately $3.0 \mathrm{~kb}$ that hybridized with ermK. By colony hybridization using ermK as the probe, four transformants showing positive signals were chosen from the 1000 colonies examined. The recombinant plasmid isolated from cultures of these transformants was used to transform B. subtilis UOTO277. B. subtilis transformants

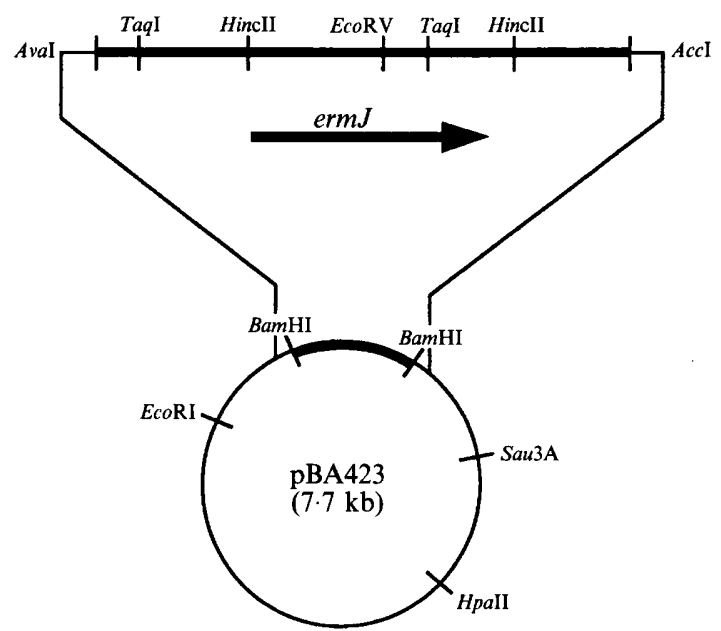

Fig. 1. Restriction map of plasmid pBA423. The thick line indicates cloned $B c l$ fragments from chromosomal DNA of $B$. anthracis 590 . The arrow indicates the direction of transcription of ermJ, the MLS resistance determinant. resistant to both Em and chloramphenicol were chosen. The inducible resistance patterns of these transformants, determined by the agar disk method, were identical to that of the original $B$. anthracis 590 . With an Em disk at the centre of each plate D-shaped inhibition zones appeared around disks containing kitasamycin or tylosin. The recombinant plasmid was designated pBA423.

Using information from the restriction endonuclease map of pBA423 (Fig. 1), the various fragments were electroeluted and inserted into the vector pBS42. By transforming B. subtilis UOTO277 with the recombinant plasmids, and testing the transformants for resistance to Em and other antibiotics, an MLS resistance gene was located on the HincII-HincII $(1.4 \mathrm{~kb})$ fragment.

The nucleotide sequence of the HincII-HincII fragment was determined (Fig. 2). The 1324 bp DNA fragment contained a small open reading frame (ORF) from nucleotide 70 to 110 encoding a leader peptide of 14 amino acids. A Shine-Dalgarno region (SD-1) was located upstream of the ORF. A large ORF from nucleotide 391 to 1252 was considered to be the ermJ structural gene encoding a methyltransferase with a deduced molecular mass of $33 \mathrm{kDa}$. Another Shine-Dalgarno region (SD-2) was located upstream of this large ORF. When the nucleotide sequence of ermJ was compared with the sequences of other erm genes, it showed similarity to those of ermK and ermD, the MLS resistance elements cloned from $B$. licheniformis (Gryczan et al., 1984; Kwak et al., 1991). There are 28 nucleotide and 9 amino acid differences between ermJ and ermK in a comparison of 1324 nucleotides and 287 amino acids (Table 2). Therefore, the MLS resistance genes are likely to be phylogenetically related. Because the leader sequence of ermJ was similar to that of ermK, expression of ermJ is also likely to be controlled by the transcriptional attenuation mechanism demonstrated for ermK (Kwak et al., 1991).

\section{Expression of ermJ in B. subtilis minicells}

The $B$. subtilis minicell system was used to identify the polypeptides expressed from ermJ. PAGE showed a faint band of $33 \mathrm{kDa}$ in the absence of Em. The intensity of the band increased when the minicells were treated with $0.1 \mu \mathrm{g} \mathrm{Em} \mathrm{ml} l^{-1}$ (Fig. 3). Since the size of the induced protein corresponded to that deduced from the DNA sequence of ermJ, the protein was thought to be the rRNA methyltransferase gene product. Protein bands of 50 and $26 \mathrm{kDa}$ showed the same intensity in the presence and absence of $\mathrm{Em}$. These proteins were presumed to be gene products of pBS42, the vector component of pBA423. The $33 \mathrm{kDa}$ protein product of ermJ is evidently produced at a basal level without Em. The presence of low concentrations of Em cause a conformational change 


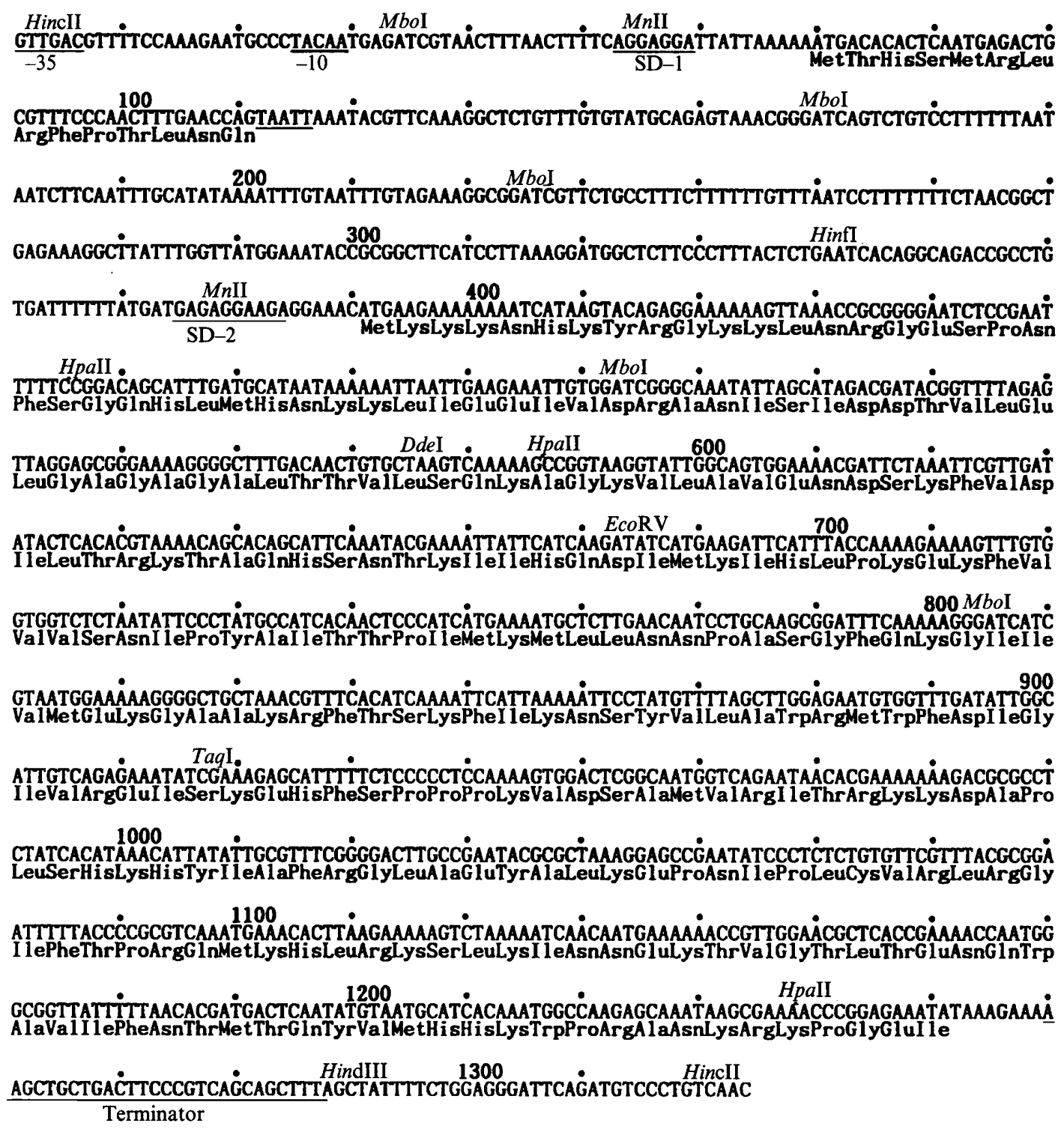

Fig. 2. Nucleotide sequence of ermJ. The positions of the ermJ promotor ( -35 and -10$)$, the probable transcriptional terminator, relevant restriction endonuclease recognition sites, Shine-Dalgarno sequences SD-1 and SD-2 and their associated initiation codons, and the termination codons of the leader peptide and methyltransferase are all underlined.

in the leader mRNA; ribosomes bind to the SD-2 region and increase expression of the rRNA methyltransferase gene.

\section{Purification of rRNA methyltransferase}

To further understand the characteristics of the gene product of ermJ, rRNA methyltransferase was purified. The amount and activity of protein for each purification step is shown in Table 3. The methyltransferase assay showed negligible activity in the supernatant obtained by centrifugation at $105000 \mathrm{~g}$. Therefore, as reported by Shivakumar \& Dubnau (1981), rRNA methyltransferase binds tightly to $70 \mathrm{~S}$ ribosomes. The enzyme could be separated from the ribosomes by washing with high salt buffer containing $1 \mathrm{M}-\mathrm{NH}_{4} \mathrm{Cl}$. The recovery of methyltransferase activity in the high-salt wash was $50 \%$ of that in the $\mathrm{S} 30$ extract. The methyltransferase activity in the $40-80 \%\left(\mathrm{NH}_{4}\right)_{2} \mathrm{SO}_{4}$ precipitate was only $60 \%$, and the amount of protein was only $5.6 \%$ of that in the high-salt wash. The elution profile (Fig. 4) from a phosphocellulose column showed that the methyltransferase was eluted at $0.4-0.6 \mathrm{M}-\mathrm{NH}_{4} \mathrm{Cl}$. The active fractions were collected and concentrated to one tenth volume by ultrafiltration and examined by SDS-PAGE. A single protein band of $33 \mathrm{kDa}$ was identified on the gel (Fig. 5); 
Table 2. Differences in nucleotide and deduced amino acid sequences between ermJ and ermK

\begin{tabular}{ccccc}
\hline \hline \multicolumn{2}{c}{ Position } & & \multicolumn{2}{c}{ Base (aa) substitution* } \\
\cline { 5 - 5 }$r e r m J$ & $e r m K$ & & ermJ & ermK \\
\hline 90 & 471 & & T (Leu) & G (Leu) \\
210 & 591 & & T & C \\
305 & 686 & & C & A \\
443 & 824 & & C (Ser) & A (Tyr) \\
558 & 939 & & G (Gly) & T (Gly) \\
571 & 952 & & G (Val) & A (Met) \\
629 & 1010 & & A (Asp) & C (Ala) \\
658 & 1039 & & T (Ser) & C (Pro) \\
1008 & 1389 & & T (Tyr) & C (Tyr) \\
$1019-20$ & $1400-1$ & & G, G (Arg) & T, T (Leu) \\
1023 & 1404 & & A (Gly) & G (Gly) \\
1035 & 1416 & & C (Tyr) & T (Tyr) \\
$1051-3$ & $1432-4$ & A, T (Asn) & C, A (Gln) \\
$1054-5$ & $1435-6$ & A, T (Ile) & G, C (Ala) \\
1060 & 1441 & C (Leu) & T (Phe) \\
$1069-70$ & $1450-1$ & C, G (Arg) & G, C (Ala) \\
1089 & 1470 & C (Thr) & T (Thr) \\
1128 & 1509 & C (Ile) & T (Ile) \\
1203 & 1584 & A (Val) & G (Val) \\
1209 & 1590 & T (His) & C (His) \\
1271 & 1652 & T & G \\
1274 & 1655 & C & T \\
1287 & 1671 & T & A \\
1292 & 1675 & A & T \\
\hline \hline
\end{tabular}

* aa, Amino acid.

this was of the same size as the protein expressed by induction in minicells. Compared with the $\left(\mathrm{NH}_{4}\right)_{2} \mathrm{SO}_{4}$ precipitate, the enzyme in the final eluate showed about 55 -fold increase in specific activity and an overall recovery of $6 \cdot 1 \%$.

\section{Characterization of $r R N A$ methyltransferase}

To determine the optimal concentration of Em for induction of ermJ, B. subtilis UOTO277 transformed with pBA423 was grown to mid-exponential phase, 0.01-10 $\mu \mathrm{g} \mathrm{Em} \mathrm{ml}{ }^{-1}$ were added to the culture broth, and the cultures were incubated for $3 \mathrm{~h}$ more. The activity

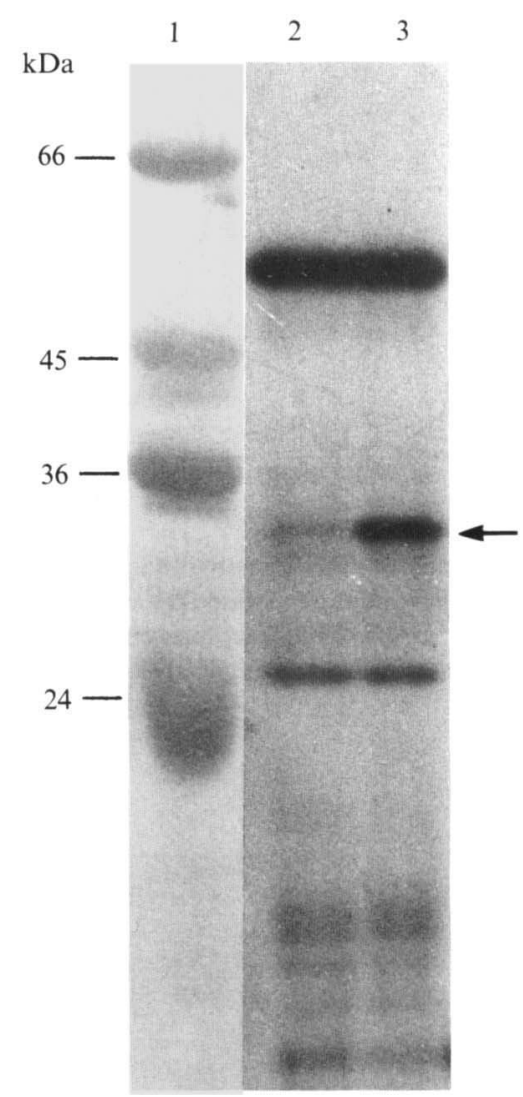

Fig. 3. Autoradiograph of a $12 \%$ SDS-polyacrylamide gel of $\left[{ }^{35}\right.$ S]methionine-labelled minicell products. Lanes: 1, molecular mass markers; 2 , products without induction; 3 , products after induction with $0.1 \mu \mathrm{g} \mathrm{Em} \mathrm{ml}^{-1}$. The arrow indicates the $33 \mathrm{kDa}$ product of ermJ.

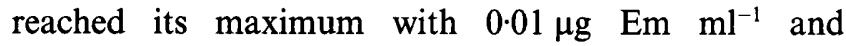

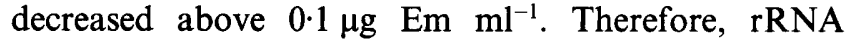
methyltransferase synthesis is probably induced to a high level at a low concentration of Em, but synthesis of the enzyme itself is inhibited by high concentrations of Em. To identify the optimal culture time after Em induction, $0.01 \mu \mathrm{g} \mathrm{Em} \mathrm{ml} \mathrm{m}^{-1}$ was added to the culture at midexponential phase. Assays for methylase activity in the culture at $1 \mathrm{~h}$ intervals showed a rapid increase in the first hour, and subsequently a slower increase until the third

Table 3. Purification of rRNA methyltransferase expressed by ermJ

\begin{tabular}{lccc}
\hline \hline Step & $\begin{array}{c}\text { Total } \\
\text { protein } \\
(\mathrm{mg})\end{array}$ & $\begin{array}{c}\text { Total } \\
\text { activity } \\
(\mathrm{U})^{*}\end{array}$ & $\begin{array}{c}\text { Specific } \\
\text { activity } \\
{\left[\mathrm{U}(\mathrm{mg} \text { protein })^{-1}\right]^{*}}\end{array}$ \\
\hline S30 extract & 514 & 1398 & $1 \cdot 2$ \\
High-salt wash & 104 & 749 & $7 \cdot 2$ \\
$40-80 \%\left(\mathrm{NH}_{4}\right)_{2} \mathrm{SO}_{4}$ precipitate & $28 \cdot 8$ & 432 & $14 \cdot 9$ \\
Phosphocellulose column eluate & $1 \cdot 3$ & $85 \cdot 3$ & $65 \cdot 6$ \\
\hline \hline
\end{tabular}

* One unit of enzyme activity is defined as the amount of enzyme required for the attachment of 1 pmol of methyl groups per $20 \mathrm{~min}$ to $50 \mathrm{~S}$ ribosomal subunits under the conditions of the assay. 


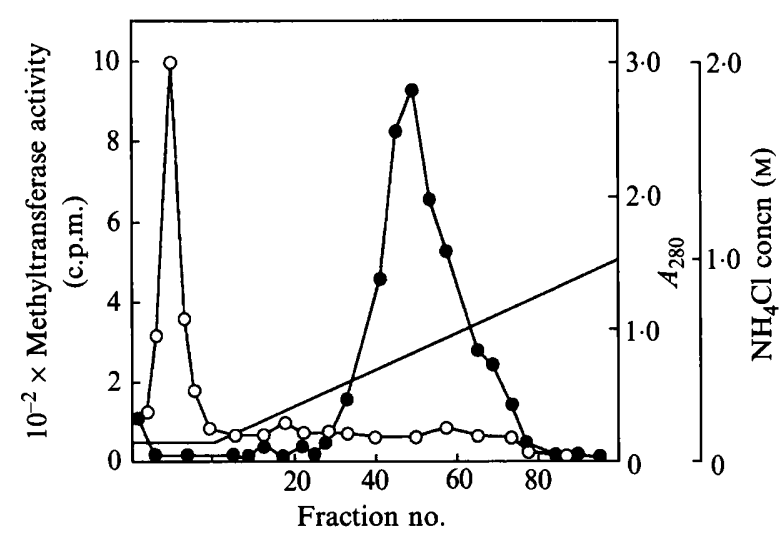

Fig. 4. Elution profile of rRNA methyltransferase during phosphocellulose column chromatography. Material was eluted with a $0 \cdot 1-1 \cdot 0 \mathrm{M}-$ $\mathrm{NH}_{4} \mathrm{Cl}$ gradient (-) and $2 \mathrm{ml}$ fractions were collected. For each fraction, $A_{280}(O)$ and rRNA methyltransferase activity $(\bullet)$ were determined.

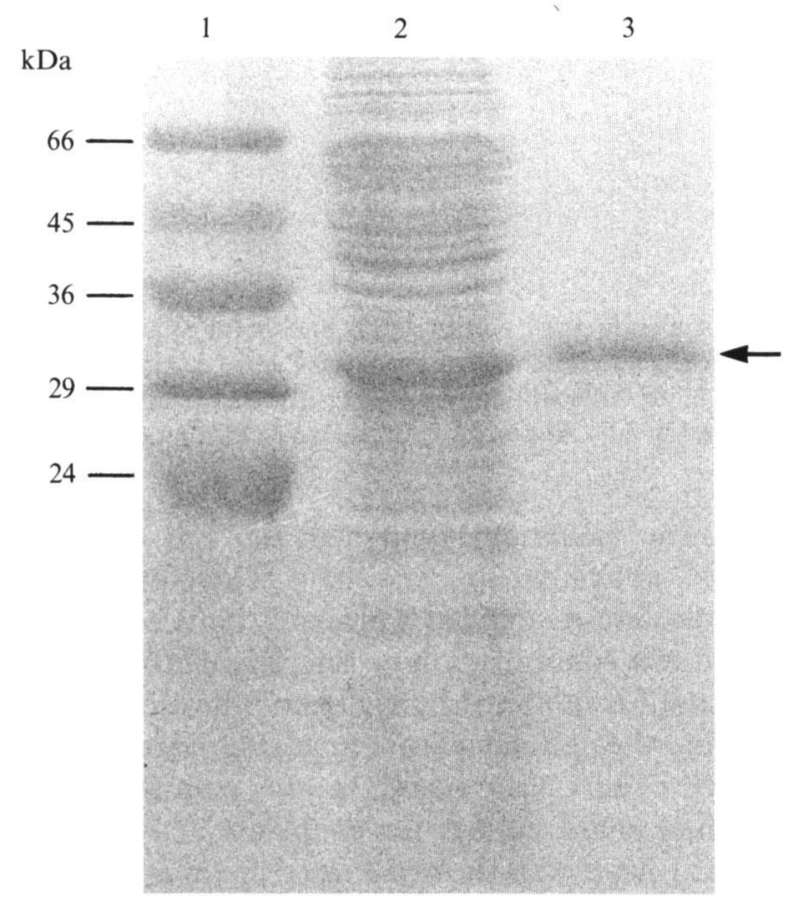

Fig. 5. SDS-PAGE $(12 \%)$ of proteins from a culture of B. subtilis UOTO277 transformed with pBA423. The gel was stained with Coomassie blue. Lanes: 1, molecular mass markers; 2, 40-80\% $\left(\mathrm{NH}_{4}\right)_{2} \mathrm{SO}_{4}$ precipitate; 3, rRNA methyltransferase purified by phosphocellulose column chromatography. The arrow indicates the $33 \mathrm{kDa}$ product of ermJ.

hour, when it remained constant. Others have invoked feedback inhibition or an autoregulation mechanism to account for the constant level of ermC product in bacterial cells (Shivakumar et al., 1980; Gryczan et al., 1978). The optimal culture time for methylase activity, following $\mathrm{Em}$ induction of ermJ was concluded to be between 1 and $3 \mathrm{~h}$.

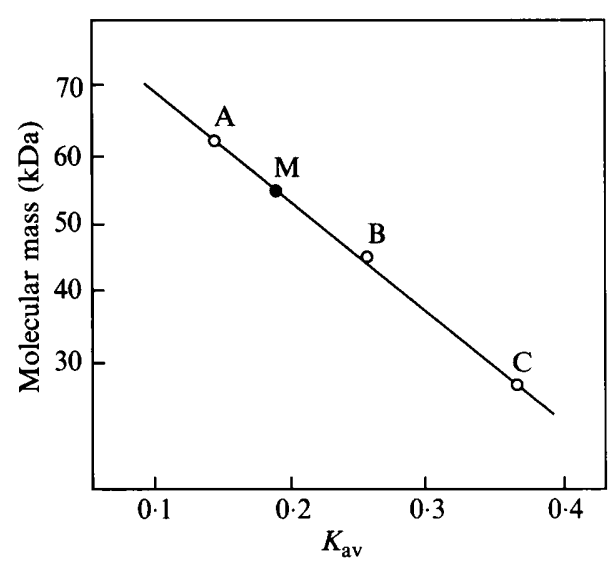

Fig. 6. Molecular mass estimation of rRNA methyltransferase by Sephadex G-100 gel permeation chromatography. Molecular mass markers $(O)$ : A, bovine serum albumin $(66 \mathrm{kDa})$; B, egg albumin $(45 \mathrm{kDa})$; C, carbonic anhydrase $(29 \mathrm{kDa})$. M (O), rRNA methyltransferase $(58 \mathrm{kDa})$.

The molecular mass of the purified rRNA methyltransferase was determined by gel permeation chromatography using Sephadex G-100. Trypsinogen ( $24 \mathrm{kDa})$, egg albumin $(45 \mathrm{kDa})$ and bovine serum albumin $(66 \mathrm{kDa})$ were included as standards. The molecular mass estimated from a $\log$ molecular mass versus $K_{\text {av }}$ plot was $58 \mathrm{kDa}$ (Fig. 6). Therefore, the enzyme is probably a homodimer of approximately $33 \mathrm{kDa}$ subunits.

The molecular mass discrepancy may be explained by a conformational change during dimer formation. The optimal temperature for the enzyme reaction was $40^{\circ} \mathrm{C}$. Activity was reduced by 90 and $30 \%$ at 45 and $60{ }^{\circ} \mathrm{C}$, respectively. Therefore, this rRNA methyltransferase has some thermal stability. The $\mathrm{pH}$ optimum for methyltransferase activity was 7.0 , and for enzyme storage at $4{ }^{\circ} \mathrm{C}, \mathrm{pH} 5$ or 6 was optimum. The enzyme showed little activity loss after 3 months at $-70^{\circ} \mathrm{C}$. The above characteristics are somewhat different from those of ermC methyltransferase as indicated in Table 4 (Shivakumar \& Dubnau, 1981; Denoya \& Dubnau, 1987).

To understand the substrate specificity of ermJ methyltransferase, the activities of the enzyme on 50S, $30 \mathrm{~S}$ and $70 \mathrm{~S}$ ribosomes from B. subtilis, and on $50 \mathrm{~S}$ ribosomes from $B$. subtilis transformed with pBA423 and induced with $\mathrm{Em}$ were compared. Three picomoles of $\mathrm{C}^{3} \mathrm{H}_{3}$ were incorporated into $15 \mathrm{pmol}$ of $50 \mathrm{~S}$ ribosomes, but only $0.3,0.6$ and $0.4 \mathrm{pmol}$ of $\mathrm{C}^{3} \mathrm{H}_{3}$ were incorporated into $30 \mathrm{~S}, 70 \mathrm{~S}$ and methylated $50 \mathrm{~S}$ ribosomes, respectively. It was concluded that the enzyme methylated $50 \mathrm{~S}$ ribosomes but not $30 \mathrm{~S}$ or $70 \mathrm{~S}$ ribosomes, or methylated $50 \mathrm{~S}$ ribosomes. Presumably it acted on free 50S ribosomes but not on $70 \mathrm{~S}$ ribosomes because the methylation site was blocked by $30 \mathrm{~S}$ ribosomes, as reported for the 
Table 4. Comparison of $r R N A$ methyltransferases expressed from ermJ and ermC

\begin{tabular}{lcc}
\hline & ermJ & ermC \\
\hline Molecular mass* & $33 \mathrm{kDa}$ & $29 \mathrm{kDa}$ \\
Molecular mass $\dagger$ & $58 \mathrm{kDa}$ & $\mathrm{NK}$ \\
Composition & Homodimer & $\mathrm{NK}$ \\
Optimal pH & $7 \cdot 0$ & $7 \cdot 5$ \\
Optimal temperature & $40^{\circ} \mathrm{C}$ & $35-37^{\circ} \mathrm{C}$ \\
$K_{\mathrm{m}}$ for 50S ribosome & $210 \mathrm{nM}$ & $375 \mathrm{nM}$ \\
$K_{\mathrm{m}}$ for SAM & $3 \cdot 18 \mu \mathrm{M}$ & $12 \mu \mathrm{M}$ \\
Substrate specificity & $50 \mathrm{~S}$ Ribosome & $50 \mathrm{~S}$ Ribosome \\
\hline \hline
\end{tabular}

NK, Not known.

* Molecular mass of protein deduced from nucleotide sequence.

† Molecular mass of natural form of protein.

ermC enzyme (Shivakumar \& Dubnau, 1981). The absence of activity with in vivo-methylated 50S ribosomes indicated that in vivo and in vitro methylation sites are the same. Moreover, since 50S ribosomes prepared from cells expressing erm $J$ were not further methylated in vitro by the ermC product, the two proteins methylate the same site in 23S rRNA. An enzyme stoichiometry study was performed, and $K_{\mathrm{m}}$ and $V_{\max }$ values for each substrate were calculated from a Lineweaver-Burk plot (Segel, 1975). The $K_{\mathrm{m}}$ values for 50S ribosomes and SAM were $210 \mathrm{nM}$ and $3.18 \mu \mathrm{M}$, respectively. The ermC enzyme has not yet been structurally analysed, and it would be desirable to characterize the erm methylases of phylogenetically-related organisms with a view to protein engineering. The interactions of the enzymes with their substrates, $50 \mathrm{~S}$ ribosomes or $23 \mathrm{~S}$ rRNAs, would also be of considerable interest.

This research was supported by the non-directed research fund, Korea Research Foundation, 1992, and by RCNDD of Seoul National University (KOSEF).

\section{References}

BAND, L. \& HENNER, D. J. (1984). Bacillus subtilis requires a stringent Shine-Dalgarno region for gene expression. DNA 3, 17-21.

BreidT, F. \& DubNaU, D. (1990). Identification of cis-acting sequences required for translational autoregulation of the ermC methylase. Journal of Bacteriology 172, 3661-3668.

CHOI, E. C., WoO, K. W., WoO, J. S., KWAK, J. H. \& KIM, B. K. (1989). The cloning of MLS antibiotics' inducible resistance gene. Archives of Pharmacal Research (Seoul) 12, 176-180.

Davis, L. G., Dibner, M. D. \& Battey, J. F. (1986). pBR322 colony hybridization. In Methods in Molecular Biology, pp. 227-229. New York: Elsevier.

Denoya, C. D. \& Dubnau, D. (1987). Site and substrate specificity of ermC 23S rRNA methyltransferase. Journal of Bacteriology 169, $3857-3860$.
Dubnau, D. (1984). Translational attenuation: the regulation of bacterial resistance to the macrolide-lincosamide-streptogramin B antibiotics. Critical Reviews in Biochemistry 16, 103-132.

FahNestock, S., ERDMANN, V. \& NomURA, M. (1974). Reconstitution of 50S ribosomal subunits from Bacillus stearothermophilus. Methods in Enzymology 30, 554-562.

Gryczan, T. J., Contente, S. \& Dubnau, D. (1978). Characterization of Staphylococcus aureus plasmid introduced by transformation into Bacillus subtilis. Journal of Bacteriology 134, 318-329.

Gryczan, T. J., Israeli-Reches, M., Del Blue, M. \& Dubnau, D. (1984). DNA sequence and regulation of ermD, a macrolidelincosamide-streptogramin B resistance element from Bacillus licheniformis. Molecular and General Genetics 194, 349-356.

Horinouchi, S., Byeon, W. H. \& Weisblum, B. (1983). A complex attenuator regulates inducible resistance to macrolides, lincosamides and streptogramin type B antibiotics in Streptococcus sanguis. Journal of Bacteriology 154, 1252-1262.

Kamimiya, S. \& Weisblum, B. (1988). Translational attenuation control of ermSF, an inducible resistance determinant encoding rRNA $N$-methyltransferase from Streptomyces fradiae. Journal of Bacteriology 170, 1800-1811.

KwaK, J. H., СhoI, E. C. \& Weisblum, В. (1991). Transcriptional attenuation control of ermK, a macrolide-lincosamidestreptogramin B resistance determinant from Bacillus licheniformis. Journal of Bacteriology 173, 4725-4735.

LECLERCQ, R. \& CouRVALIN, P. (1991). Intrinsic and unusual resistance to macrolide, lincosamide and streptogramin antibiotics in bacteria. Antimicrobial Agents and Chemotherapy 35, 1273-1276.

MEAD, D. A. \& KeMPER, B. (1988). In Vectors: A Survey of Molecular Cloning Vectors and Their Uses, pp. 85-111. Edited by R. C. Rodrigues \& D. T. Denhardt. Stoneham, MA: Butterworth Publishing Co.

Miller, J. H. (1972). Experiments in Molecular Genetics, Cold Spring Harbor, NY: Cold Spring Harbor Laboratory.

Monod, M., Mohan, S. \& Dubnau, D. (1987). Cloning and analysis of ermG, a new macrolide-lincosamide-streptogramin B resistance element from Bacillus sphaericus. Journal of Bacteriology 169, 340-350.

MURPHY, E. (1985). Nucleotide sequence of ermA, a macrolidelincosamide-streptogramin B determinant in Staphylococcus aureus. Journal of Bacteriology 162, 633-640.

Reeve, J. N., Mendelson, N. H., Coyne, S. I., Hallock, L. L. \& Cole, R. M. (1973). Minicells of Bacillus subtilis. Journal of Bacteriology 114, 860-873.

SANGer, F., Nicklen, S. \& Coulson, A. R. (1977). DNA sequencing with chain-terminating inhibitors. Proceedings of the National Academy of Sciences of the United States of America 74, 5463-5467.

SEGEL, I. H. (1975). Enzyme Kinetics. London: Wiley.

Shivakumar, A. G. \& Dubnau, D. (1981). Characterization of a plasmid-specified ribosome methylase associated with macrolide resistance. Nucleic Acids Research 9, 2549-2562.

Shivakumar, A. G., Hahn, J. \& Dubnau, D. (1979). Studies on the synthesis of plasmid-coded proteins and their control in Bacillus subtilis minicells. Plasmid 2, 279-289.

Shivakumar, A. G., Hahn, J., Grandi, G., Kozlov, Y. \& Dubnau, D. (1980). Posttranscriptional regulation of an erythromycin resistance specified by plasmid pE194. Proceedings of the National Academy of Sciences of the United States of America 77, 3903-3907.

SOUTHERN, E. M. (1975). Detection of specific sequences among DNA fragments separated by electrophoresis. Journal of Molecular Biology 98, 503-517.

WeISBLUM, B. (1985). Inducible resistance to macrolides, lincosamides and streptogramin type B antibiotics: the resistance phenotype, its biological diversity, and structural elements that regulate expression. In Gene Function in Prokaryotes, pp. 91-121. Edited by J. Beckwith, J. Davies \& J. A. Gallant. Cold Spring Harbor, NY: Cold Spring Harbor Laboratory. 